\title{
EDITORIAL
}

\section{Ainda como árvore...}

Estou cada vez mais convencido de que as árvores nos inspiram e nos ensinam todo tempo, cada qual com seu exemplo de vida. E a Revista Engenharia de Interesse Social chega a mais uma florada, como um Ipê Amarelo que, mesmo sem suas folhas e em condições adversas, nos mostra que estar de pé não é fácil, mas é preciso florir e mostrar a sociedade que é possível dar bons frutos ou bonitas flores mesmo em solos mal tratados, como temos observado no solo acadêmico e científico.

Alguém já viu uma floresta só de Ipês!? Não! É porque essa árvore também nos ensina que devemos crescer e viver na diversidade, entre os diferentes, respeitando as diferenças e os tempos distintos de desenvolvimento de cada espécie! Sem arrogância e sem vaidade, assim, simplesmente, os Ipês nos encantam!

Inspirada por esse belíssimo exemplo, a equipe da REIS lança o 4o número do periódico com um conjunto de textos que atende a diversidade de temas que caracteriza a sua essência e que, mesmo contrariando alguns, ENRIQUECEM a formação de engenheiros, SIM! E de tantos outros estudiosos por explorar temas como o abordado no texto $O$ Programa Milton Santos de acesso ao Ensino Superior - PROMISAES: uma Política Pública Educacional para A promoção da Democracia Social que aborda a importância da democracia racial no Brasil por meio de uma política pública educacional.

Mais há também a abordagem de problemas como impermeabilização do solo e drenagem urbana que configuram a realidade de muitas cidades carentes de uma infraestrutura adequada para suportar chuvas frequentes ou volumosas. Esta problemática é tratada no texto Inundações Urbanas e as Técnicas de Redução de Escoamento Superficial de Águas Pluviais.

A Estatística e a Matemática também enriquecem nosso bosque literário e científico ao tratar do ciclo hidrológico afetado pela degradação ambiental que tem acarretado perdas na vazão dos rios e, consequentemente, na produção agrícola por meio de um modelo probabilístico constante no texto 0 Modelo Probabilístico Gumbel no ajustamento da Vazão Máxima do Córrego Norete.

Como suplemento da nossa diversidade, a Química e a Engenharia de Minas dão as suas contribuições analíticas e científicas por meio dos textos Seletividade da Amilopectina e Amilose na Flotação Catiônica Reversa do Minério De Ferro, Caracterização Mineralógica de Minério de Pegmatitos Litiníferos da região de Araçuaí - MG e Caracterização de rejeito do beneficiamento de esmeraldas visando seu aproveitamento no setor agrícola.

Por fim, mas muito longe de ser menos importante, tratamos de uma questão social de extrema relevância - o ensino de ciências - por meio do texto Transdisciplinaridade e Tecnologia: Projeto de Descarte de Pilhas e Baterias que se configura num grande desafio para a sociedade e, em especial, para os jovens que nasceram e estão sendo educados num momento de crescimento exponencial de uso desse material.

Mesmo aos que ainda acreditam que as Engenharias devam ser reduzidas a números e cálculos, desejo uma ótima e fecunda leitura!

Robson Pereira de Lima. 